\title{
Assessment of the Suitability of Temperature and Relative Humidity for Rice Cultivation in Rainfed Lowland Paddy Fields in Kurunegala District
}

\author{
W.M.U.K. Rathnayake ${ }^{*}$, R.P. De Silva ${ }^{1}$ and N.D.K. Dayawansa ${ }^{1}$ \\ Postgraduate Institute of Agriculture \\ University of Peradeniya \\ Sri Lanka
}

\begin{abstract}
Climatic Suitability analysis is a prerequisite to achieve optimum utilization of the available resources in rainfed rice cultivation. Therefore, a study was conducted to assess the climatic factors and to map their suitability for rainfed paddy farming in Mahananeriya, Ibbagamuwa and Alawwa ASC regions representing dry, Intermediate and wet areas of Kurunegala District in Yala and Maha seasons using Geo-Informatics. Daily weather data of maximum temperature, minimum temperature, and relative humidity for 10 years were averaged on a weekly basis. The IDW interpolation technique was used to prepare thematic maps. The maximum temperature was grouped as $27{ }^{\circ} \mathrm{C}-32{ }^{\circ} \mathrm{C}, 32{ }^{\circ} \mathrm{C}-35$ ${ }^{0} \mathrm{C}$, and more than $35{ }^{\circ} \mathrm{C}$. The minimum temperature was grouped as less than $19{ }^{\circ} \mathrm{C}$ and more than $19{ }^{\circ} \mathrm{C}$. Relative humidity was grouped into three classes as 60\% - 80\%, $80 \%$ $85 \%$ and more than $85 \%$. The temperature maps and relative humidity maps were overlaid with the weighted sum technique giving weights as 0.75 and 0.25 respectively to produce suitability maps for rice cultivation on weekly basis throughout the year. Results show that minimum temperature is not in the critical level for rice cultivation within Kurunegala District throughout the year. Maximum temperature is optimum $\left(27{ }^{\circ} \mathrm{C}-32{ }^{\circ} \mathrm{C}\right)$ for rice cultivation in all three ASC regions during Maha season and in Ibbagamuwa and Alawwa ASCs during Yala season. Relative humidity in all three ASCs is more than $85 \%$ during Maha season and in between $80 \%$ and $85 \%$ during Yala season. Considering temperature and relative humidity, whole rainfed paddy lands in Ibbagamuwa and Alawwa ASCs are highly suitable for rice cultivation in the Yala season. Rainfed paddy lands in all three ASCs are in suitable category in terms of the suitability of temperature and relative humidity during Maha season. Spatial variations of the suitability of the interactive outcome of the maximum temperature and relative humidity appear among Mahananeriya, Ibbagamuwa and Alawwa ASC regions representing Dry (DL1b), Intermediate (IL1a) and Wet (WL3) zones in Kurunegala District. Intra regional spatial variations are very rare. Temporal variations among two seasons of Yala and Maha and the intra variations within the seasons also evidence. Date of seed sowing or crop establishment should be aligned according to the suitability levels matching with the flowering and grain filling stages of rice.
\end{abstract}

Keywords: Rice cultivation, Rainfed lowland fields, Relative humidity, Temperature

\footnotetext{
1 Department of Agricultural Engineering, Faculty of Agriculture, University of Peradeniya, Peradeniya, Sri Lanka

* Corresponding author: upurl@yahoo.co.uk
} 


\section{INTRODUCTION}

Growth and grain yield of rice depend on the combination effect of genetic characteristics of the variety and environmental condition of the area where the variety is grown (De Datta, 1970). Environment has two components, the natural environment which includes the elements of weather, the soil and the biotic environment and the environment introduced by man in his attempt to maximize the grain yield such as fertilizer, insecticide, herbicide applications etc (De Datta, 1970). Among all the environment factors, temperature and relative humidity play a major role in rice yield. The optimum temperature for the normal development of rice plant ranges from $27{ }^{\circ} \mathrm{C}$ to $32{ }^{\circ} \mathrm{C}$ (Yin et al., 1996). High temperature affects almost all the growth stages of rice, i.e. from emergence to ripening and harvesting (Yoshida, 1978; Yoshida, 1981, Satake \& Yoshida 1978; Morita et al., 2004). However, flowering (anthesis and fertilization) and booting (microsporogenesis) are considered to be the stages of most susceptible to temperature in rice (Satake \& Yoshida, 1978; Farrell et al., 2006). Temperatures higher than the optimum induce floret sterility and thus decreased rice yield (Nakagawa et al., 2003). Spikelet sterility is greatly increased at temperatures higher than $35{ }^{\circ} \mathrm{C}$ (Satake \& Yoshida, 1978; Matsui et al., 1997) which is the critical maximum temperature in rice. Night temperature of less than $19{ }^{\circ} \mathrm{C}$ is the critical low temperature for inducing grain sterility in rice (Abeysiriwardena et al., 2002). Humidity also plays an important role in rice yield, as higher relative humidity at the flowering stage under increased temperature negatively affects spikelet fertility (Yan et al., 2010). A relative humidity of 85$90 \%$ at the heading stage induces almost complete grain sterility in rice at a day/night temperature of $35 / 30{ }^{0} \mathrm{C}$ (Abeysiriwardena et al., 2002). Weerakoon et al. (2008) reported that spikelet fertility was not always inhibited by high humidity, because at low temperature, fertility was high. Both higher maximum and higher minimum temperatures with high relative humidity decrease rice yields due to spikelet sterility (Peng et al., 2004). Combined effect of temperature and relative humidity is a predominant controlling factor in rice cultivation due to their spatial and temporal variability. Spatial and temporal variations of temperature and relative humidity could be mapped and their auditability for rice cultivation can be assessed using Geographical Information Systems. This study was conducted to map and assess the maximum and minimum temperature and relative humidity in the study area to identify their suitability for rainfed paddy farming in Dry, Intermediate and Wet areas of Kurunegala District in Yala and Maha seasons using Geo-Informatics.

\section{METHODOLOGY}

\section{Study area}

Three Agrarian Service Centers (ASC) named Mahananeriya, Ibbagamuwa and Alawwa in Kurunegala District were selected as the study sites. Mahananeriya, Ibbagamuwa and Alawwa represent three major climatic zones as Dry (DL1b), Intermediate (IL1a) and Wet (WL3) in the District, respectively (Fig. 1). DL1b, IL1a and WL3 are agro ecological regions in three climatic zones respectively. 


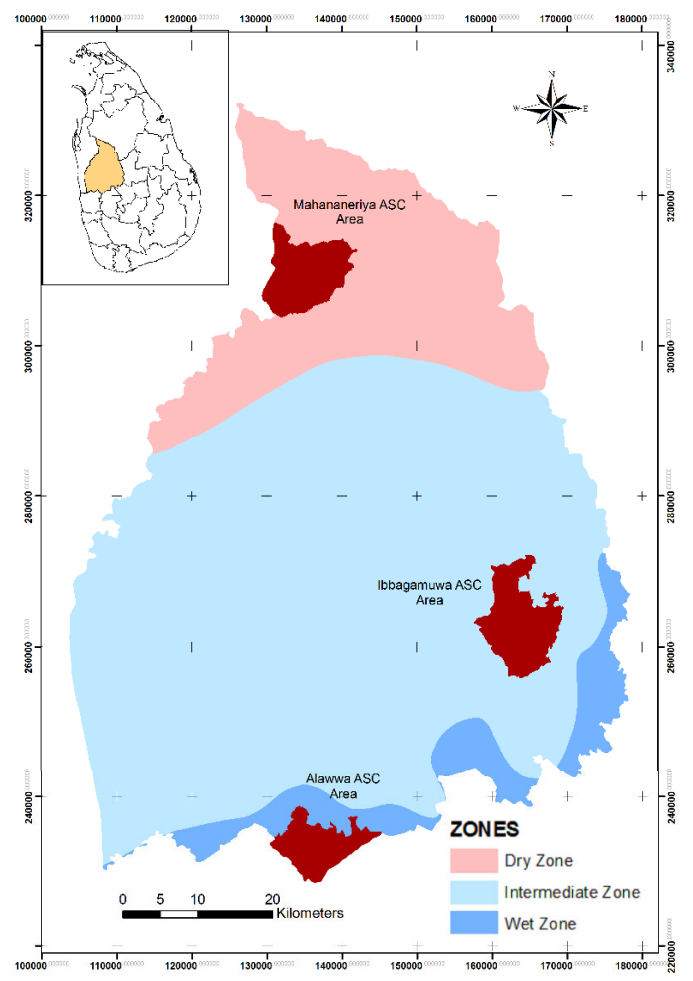

Fig. 1. Map of the study areas: Mahananeriya (DZ), Ibbagamuwa (IZ) and Alawwa (WZ) in Kurunegala District

\section{Data collection}

1:10,000 map sheets prepared by the Survey Department of Sri Lanka was used as the base map of the study. Rainfed paddy areas were extracted from the paddy cultivated areas in these maps for the three ACS regions. Daily weather data of maximum and minimum temperature, relative humidity from 2003 to 2012 were recorded from the weather stations of the Department of Meteorology at Kurunegala, Bathalagoda, Makandura, and Maho which are located in Kurunegala District and Puttalam, Ambakele, Rathmalgara, Lunuwila, Gannoruwa, Matale, Polonnaruwa, Mahailluppallama and Vauniya which are located in outside the District were used to obtain a high accuracy in mapping (Fig. 2). 


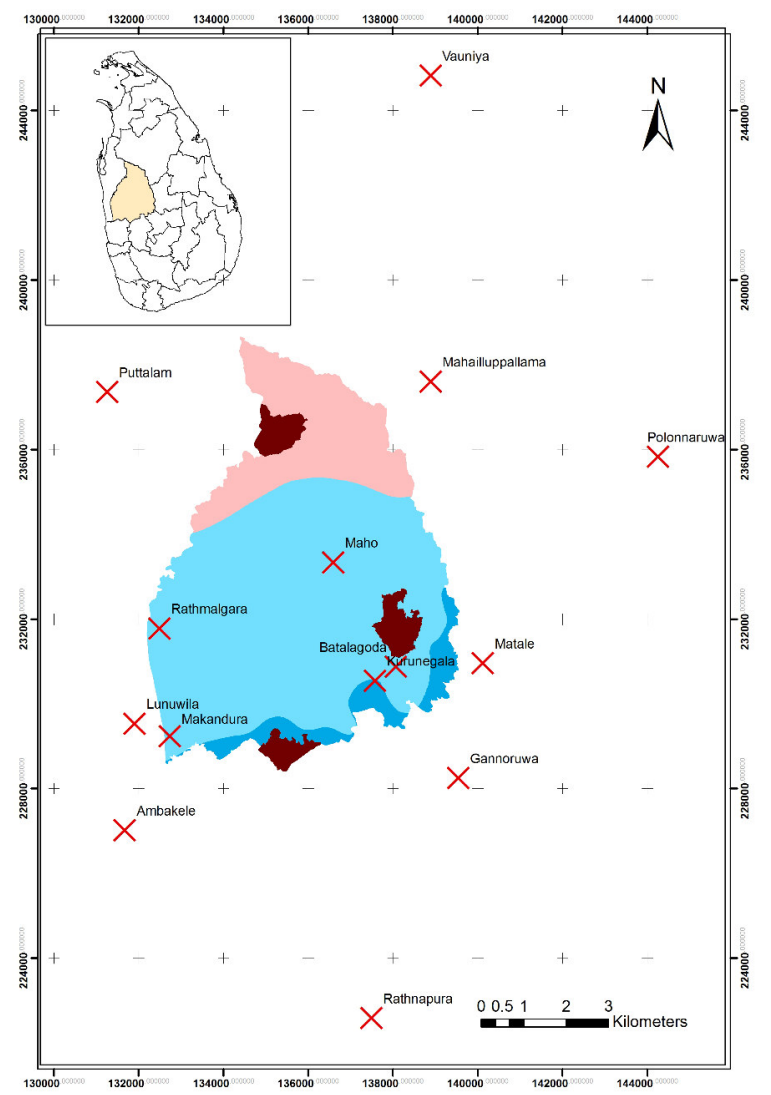

Fig. 2. Location map of the meteorological stations used in the analysis

\section{Data analysis and map preparation}

Daily weather data of maximum and minimum temperature, and relative humidity for 10 years were averaged on a weekly basis. Maps were prepared for each parameter on weekly basis throughout the year for Kurunegala District. The Inverse Distance Weighted (IDW) interpolation technique was used to prepare thematic maps (Kurtzman et al., 1999; Mussie et al., 2010). The minimum temperature was categorized as less than $19{ }^{\circ} \mathrm{C}$ and more than 19 ${ }^{0} \mathrm{C}$. The maximum temperature was grouped as $27{ }^{\circ} \mathrm{C}-32{ }^{\circ} \mathrm{C}, 32{ }^{\circ} \mathrm{C}-35{ }^{\circ} \mathrm{C}$, and more than $35{ }^{0} \mathrm{C}$. Maximum temperature between $27{ }^{\circ} \mathrm{C}$ and $32{ }^{\circ} \mathrm{C}$ was identified as the optimum for rice cultivation (Yin et al., 1996). Relative humidity was divided into three classes as $60 \%$ $80 \%, 80 \%-85 \%$ and more than $85 \%$. Optimum relative humidity for rice cultivation lies between $60 \%$ and $80 \%$ and more than $85 \%$ is the most critical level. The temperature maps and relative humidity maps were overlaid with the weighted sum technique giving weights as 0.75 and 0.25 respectively (Zeinab et al., 2014) to produce suitability maps for rice cultivation on weekly basis throughout the year. Land parcels having temperature between 27 ${ }^{0} \mathrm{C} \& 32{ }^{\circ} \mathrm{C}$ and less than $85 \%$ relative humidity were categorized as highly suitable areas. Classification of suitability classes is shown in Table 1. Maps were presented for Mahananeriya, Ibbagamuwa and Alawwa ASCs which represent Dry (DL1b), Intermediate (IL1a) and Wet (WL3) zones respectively. 
Table 1. Classification of suitability classes of maximum temperature and relative humidity

\begin{tabular}{ccc}
\hline $\begin{array}{c}\text { Classes of Maximum } \\
\left.\text { temperature } \mathbf{(}^{\mathbf{0}} \mathbf{C}\right)\end{array}$ & $\begin{array}{c}\text { Classes of Relative } \\
\text { Humidity (\%) }\end{array}$ & Suitability class \\
\hline $27-32$ & $60-80$ & Highly Suitable \\
\cline { 2 - 3 } & $80-85$ & Highly Suitable \\
\cline { 2 - 3 } & $>85$ & Suitable \\
\cline { 2 - 3 } & $60-80$ & Suitable \\
\cline { 2 - 3 } & $80-85$ & Moderately Suitable \\
\hline$>35-35$ & $>85$ & Moderately Suitable \\
\cline { 2 - 3 } & $60-80$ & Marginally Suitable \\
\cline { 2 - 3 } & $80-85$ & Not Suitable \\
\hline
\end{tabular}

\section{RESULTS AND DISCUSSION}

\section{Minimum temperature}

Exposure to cold temperature affects all phenological stages of rice and lower grain production and yield, too. Critical stages for cold damage include germination, booting, flowering, and filling stages. The most sensitive stage for cold injury is the flowering stage, which occurs 10-12 days prior to heading (Ghadirnezhad et al., 2014). Minimum temperature of less than $19{ }^{0} \mathrm{C}$ is the critical low temperature for inducing grain sterility in rice (Abeysiriwardena et al., 2002). 
Table 2. Time period for Yala and Maha seasons of minimum temperature ranges at Mahananeriya, Ibbagamuwa and Alawwa ASC areas

\begin{tabular}{|c|c|c|c|c|c|c|c|c|c|c|c|c|c|c|c|c|c|c|c|c|c|c|c|c|c|c|}
\hline \multicolumn{27}{|c|}{ Yala (Weeks from $4^{\text {th }}$ March to $2^{\text {nd }}$ September) } \\
\hline & 10 & 11 & 12 & 13 & 14 & 15 & 16 & 17 & 18 & 19 & 20 & 21 & 22 & 23 & 24 & 25 & 26 & 27 & 28 & 29 & 30 & 31 & 32 & 33 & 34 & 35 \\
\hline \multicolumn{27}{|c|}{ Mahananeriya } \\
\hline$<19^{0} \mathrm{C}$ & & & & & & & & & & & & & & & & & & & & & & & & & & \\
\hline$>19{ }^{\circ} \mathrm{C}$ & & & & & & & & & & & & & & & & & & & & & & & & & & \\
\hline \multicolumn{27}{|c|}{ Ibbagamuwa } \\
\hline$<19^{\circ} \mathrm{C}$ & & & & & & & & & & & & & & & & & & & & & & & & & & \\
\hline$>19^{\circ} \mathrm{C}$ & & & & & & & & & & & & & & & & & & & & & & & & & & \\
\hline \multicolumn{27}{|c|}{ Alawwa } \\
\hline$<19{ }^{\circ} \mathrm{C}$ & & & & & & & & & & & & & & & & & & & & & & & & & & \\
\hline$>19^{0} \mathrm{C}$ & & & & & & & & & & & & & & & & & & & & & & & & & & \\
\hline \multicolumn{27}{|c|}{ Maha (Weeks from $2^{\text {nd }}$ September to $4^{\text {th }}$ March) } \\
\hline & 36 & 37 & 38 & 39 & 40 & 41 & 42 & 43 & 44 & 45 & 46 & 47 & 48 & 49 & 50 & 51 & 52 & 01 & 02 & 03 & 04 & 05 & 06 & 07 & 08 & 09 \\
\hline \multicolumn{27}{|c|}{ Mahananeriya } \\
\hline$<19{ }^{\circ} \mathrm{C}$ & & & & & & & & & & & & & & & & & & & & & & & & & & \\
\hline$>19^{\circ} \mathrm{C}$ & & & & & & & & & & & & & & & & & & & & & & & & & & \\
\hline \multicolumn{27}{|c|}{ Ibbagamuwa } \\
\hline$<19{ }^{\circ} \mathrm{C}$ & & & & & & & & & & & & & & & & & & & & & & & & & & \\
\hline$>19^{\circ} \mathrm{C}$ & & & & & & & & & & & & & & & & & & & & & & & & & & \\
\hline \multicolumn{27}{|c|}{ Alawwa } \\
\hline$<19^{0} \mathrm{C}$ & & & & & & & & & & & & & & & & & & & & & & & & & & \\
\hline$>19^{0} \mathrm{C}$ & & & & & & & & & & & & & & & & & & & & & & & & & & \\
\hline
\end{tabular}


Results show that the minimum temperature within the district varies from $19.7{ }^{\circ} \mathrm{C}$ to $25.1{ }^{0} \mathrm{C}$ throughout the year. In the Maha season, it varies from $19.7{ }^{\circ} \mathrm{C}$ to $23.7{ }^{\circ} \mathrm{C}$ and for Yala season $20.9{ }^{0} \mathrm{C}$ to $25.1{ }^{0} \mathrm{C}$. Ten year averages show that the whole district is in the highly suitable range in terms of minimum temperature (Table 2). Therefore, $100 \%$ of total rainfed paddy lands in three selected study sites are highly suitable for rice cultivation based on minimum temperature.

\section{Maximum temperature}

High temperature affects almost all the growth stages of rice. Threshold temperature at emergence is $40{ }^{0} \mathrm{C}$, which can delay and decrease seedling emergence (Yoshida, 1978). Poor growth of the seedling occurs at $35^{\circ} \mathrm{C}$ which is the threshold temperature at seedling (Yoshida, 1981). Temperature of $32{ }^{\circ} \mathrm{C}$ reduces tillering and height (Yoshida, 1978) and floret sterility occurs at $35{ }^{\circ} \mathrm{C}$ (Satake \& Yoshida, 1978). Threshold temperatures of $33.7{ }^{\circ} \mathrm{C}$ and $34{ }^{\circ} \mathrm{C}$ cause poor anther dehiscence, sterility and yield reduction respectively (Jagadish et al., 2007; Morita et al., 2004). Considering these figures, maximum temperature was categorized as optimum $\left(27{ }^{\circ} \mathrm{C}-32{ }^{0} \mathrm{C}\right)$ throughout the growing season, and threshold or critical (more than $35^{\circ} \mathrm{C}$ ) which is the threshold level for the most critical stage of flowering (Satake \& Yoshida 1978; Matsui et al., 1997). Since these information are not available for Indica rice varieties, values for Japonica varieties were used. Maps showed that maximum temperature within the district varies from $28.8{ }^{\circ} \mathrm{C}$ to $35.5{ }^{\circ} \mathrm{C}$ throughout the year. It is in between $28.8{ }^{\circ} \mathrm{C}$ and $34.9{ }^{\circ} \mathrm{C}$ in Maha season and it varies from $30.1{ }^{\circ} \mathrm{C}$ to $35.5{ }^{\circ} \mathrm{C}$ in Yala season. Data from Bathalagoda shows the lowest values of maximum temperature for both Yala and Maha seasons. While showing the highest values of maximum temperature in Maho station for both seasons, data in Makandura station shows the highest values from mid December to end of February. However, ten year averages show that the whole district is in the "highly suitable" and "suitable" range in terms of maximum temperature (Table 3). 
Table 3. Time period for Yala and Maha seasons of maximum temperature ranges at Mahananeriya, Ibbagamuwa and Alawwa ASC areas

\begin{tabular}{|c|c|c|c|c|c|c|c|c|c|c|c|c|c|c|c|c|c|c|c|c|c|c|c|c|c|c|}
\hline \multicolumn{27}{|c|}{ Yala (Weeks from $4^{\text {th }}$ March to $2^{\text {nd }}$ September) } \\
\hline & 10 & 11 & 12 & 13 & 14 & 15 & 16 & 17 & 18 & 19 & 20 & 21 & 22 & 23 & 24 & 25 & 26 & 27 & 28 & 29 & 30 & 31 & 32 & 33 & 34 & 35 \\
\hline \multicolumn{27}{|c|}{ Mahananeriya } \\
\hline $27-32{ }^{0} \mathrm{C}$ & & & & & & & & & & & & & & & & & & & & & & & & & & \\
\hline $32-35{ }^{0} \mathrm{C}$ & & & & & & & & & & & & & & & & & & & & & & & & & & \\
\hline \multicolumn{27}{|c|}{ Ibbagamuwa } \\
\hline $27-32{ }^{0} \mathrm{C}$ & & & & & & & & & & & & & & & & & & & & & & & & & & \\
\hline $32-35{ }^{0} \mathrm{C}$ & & & & & & & & & & & & & & & & & & & & & & & & & & \\
\hline \multicolumn{27}{|c|}{ Alawwa } \\
\hline $27-32{ }^{0} \mathrm{C}$ & & & & & & & & & & & & & & & & & & & & & & & & & & \\
\hline $32-35{ }^{0} \mathrm{C}$ & & & & & & & & & & & & & & & & & & & & & & & & & & \\
\hline \multicolumn{27}{|c|}{ Maha (Weeks from $2^{\text {nd }}$ September to $4^{\text {th }}$ March) } \\
\hline & 36 & 37 & 38 & 39 & 40 & 41 & 42 & 43 & 44 & 45 & 46 & 47 & 48 & 49 & 50 & 51 & 52 & 01 & 02 & 03 & 04 & 05 & 06 & 07 & 08 & 09 \\
\hline \multicolumn{27}{|c|}{ Mahananeriya } \\
\hline $27-32{ }^{0} \mathrm{C}$ & & & & & & & & & & & & & & & & & & & & & & & & & & \\
\hline $32-35{ }^{0} \mathrm{C}$ & & & & & & & & & & & & & & & & & & & & & & & & & & \\
\hline & & & & & & & & & & & $\mathrm{Ibb}$ & gam & & & & & & & & & & & & & & \\
\hline $27-32{ }^{\circ} \mathrm{C}$ & & & & & & & & & & & & & & & & & & & & & & & & & & \\
\hline $32-35{ }^{\circ} \mathrm{C}$ & & & & & & & & & & & & & & & & & & & & & & & & & & \\
\hline & & & & & & & & & & & & aww & & & & & & & & & & & & & & \\
\hline $27-32{ }^{0} \mathrm{C}$ & & & & & & & & & & & & & & & & & & & & & & & & & & \\
\hline $32-35^{\circ} \mathrm{C}$ & & & & & & & & & & & & & & & & & & & & & & & & & & \\
\hline
\end{tabular}


All the maximum temperature values are less than $35^{\circ} \mathrm{C}$. These values are based on ten year average on weekly basis. However, daily maximum temperature values in some years are more than $35^{\circ} \mathrm{C}$ which is more critical for yield reduction. Threshold temperatures of 33.7 ${ }^{0} \mathrm{C}$ and $34{ }^{0} \mathrm{C}$ which are in between $32{ }^{\circ} \mathrm{C}-35{ }^{\circ} \mathrm{C}$ cause poor anther dehiscence, sterility and yield reduction respectively (Jagadish et al., 2007; Morita et al., 2004). Therefore, time duration which lies between the optimum value of maximum temperature $\left(27{ }^{\circ} \mathrm{C}-32{ }^{\circ} \mathrm{C}\right)$ can be considered as the most suitable period for reproductive stage of rice.

Mahananeriya ASC region receives the maximum temperature level $\left(27{ }^{\circ} \mathrm{C}-32{ }^{\circ} \mathrm{C}\right)$ which is optimum for rice from $10^{\text {th }}$ June $\left(24^{\text {th }}\right.$ week) to $28^{\text {th }}$ July $\left(30^{\text {th }}\right.$ week) during Yala season. In the mean time, part of Mahananeriya region receives $32{ }^{0} \mathrm{C}$ to $35{ }^{0} \mathrm{C}$ during $24^{\text {th }}, 26^{\text {th }}, 27^{\text {th }}$, and $28^{\text {th }}$ weeks. Therefore, entire area of Mahanaeriya ASC receives the optimum temperature from $15^{\text {th }}$ July to $28^{\text {th }}$ July $\left(29^{\text {th }}\right.$ and $30^{\text {th }}$ weeks) in Yala season. In Maha season, from $21^{\text {st }}$ September $\left(43^{\text {rd }}\right.$ week) to $11^{\text {th }}$ February $\left(6^{\text {th }}\right.$ week) receives optimum temperature in whole Mahananeriya ASC region.

Ibbagamuwa ASC region receives maximum temperature level $\left(27{ }^{0} \mathrm{C}-32{ }^{0} \mathrm{C}\right)$ which is optimum for rice from $20^{\text {th }}$ May $\left(21^{\text {st }}\right.$ week) to the end of Yala season while receiving the temperature from $27{ }^{0} \mathrm{C}$ to $32{ }^{0} \mathrm{C}$ from $5^{\text {th }}$ August $\left(32^{\text {nd }}\right.$ week) some part of the region. Accordingly, the best time period lies in between $10^{\text {th }}$ June $\left(24^{\text {th }}\right.$ week $)$ and $4^{\text {th }}$ August $(31$ week) in terms of maximum temperature during Yala season. Up to $11^{\text {th }}$ February from the beginning of Maha season, optimum level of maximum temperature is received by Ibbagamuwa ASC region, while receiving $32{ }^{\circ} \mathrm{C}$ to $35^{\circ} \mathrm{C}$ from $16{ }^{\text {th }}$ September $\left(38^{\text {th }}\right.$ week) to $13^{\text {th }}$ October $\left(41^{\text {st }}\right.$ week) for a part of the region. From $14^{\text {th }}$ October to $11^{\text {th }}$ February $\left(42^{\text {nd }}\right.$ to $6^{\text {th }}$ week), maximum temperature is in optimum level for the entire Ibbagamuwa ASC region during Maha season.

During Yala season, entire Alawwa ASC region receives optimum level of maximum temperature for rice from $27^{\text {th }}$ May to $1^{\text {st }}$ September. From the beginning of Maha season to $28^{\text {th }}$ January maximum temperature is optimum for the whole region.

\section{Relative Humidity}

Optimum relative humidity for rice cultivation lies between $60 \%$ and $80 \%$ (Nguyen, 2003). Since these information are not available for Indica rice varieties, values for Japonica varieties were used. More than $85 \%$ of relative humidity with high temperature of more than $35^{\circ} \mathrm{C}$ is the most critical level for high sterility (Abeysiriwardena et al., 2002; Weerakoon et al., 2008). Relative humidity within the district varies from $64 \%$ to $95 \%$ throughout the year. In the Maha season, it varies from $78 \%$ to $91 \%$ and in Yala season it varies from $76 \%$ to $87 \%$. Throughout the year, the lowest values were recorded in Maho and Kurunegala meteorological stations and the highest relative humidity was recorded at Bathalagoda station within the district. From $6^{\text {th }}$ May to $6^{\text {th }}$ October, part of the district is covered by optimum level of relative humidity and from $14^{\text {th }}$ October to $27^{\text {th }}$ August, part of the district is covered by the critical level of relative humidity. Throughout the year, rest of the part is covered by $80 \%-85 \%$ relative humidity.

Table 4 shows that the relative humidity in Mahanaeriya ASC region is preferable from $10^{\text {th }}$ June $\left(24^{\text {th }}\right.$ week) during Yala season and does not reach to threshold (>85\%) throughout the season. In Maha season, at the beginning it reaches to optimum value of relative humidity $(60-80 \%)$. From $21^{\text {st }}$ October $\left(43^{\text {rd }}\right.$ week $)$ to $18^{\text {th }}$ February $\left(7^{\text {th }}\right.$ week $)$ relative humidity is more than $85 \%$ in the region. 
From $15^{\text {th }}$ April $\left(16^{\text {th }}\right.$ week) to $4^{\text {th }}$ August $\left(31^{\text {st }}\right.$ week) Ibbagamuwa ASC region is covered by $80 \%-85 \%$ relative humidity during Yala season. Whole area is covered by more than $85 \%$ and $80 \%-85 \%$ relative humidity from $14^{\text {th }}$ October $\left(42^{\text {nd }}\right.$ week) to the end of the Maha season.

Whole Alawwa ASC region is covered by $80 \%$ - $85 \%$ category of relative humidity during Yala season and the entire area is in the threshold level from $21^{\text {st }}$ October to $22^{\text {nd }}$ December during Maha season.

In terms of relative humidity, it is preferable in Yala season than the Maha season in all three ASC regions located in Dry, Intermediate and Wet zones in Kurunegala District. 
Table 4. Time period for Yala and Maha seasons of relative humidity ranges at Mahananeriya, Ibbagamuwa and Alawwa ASC areas

\begin{tabular}{|c|c|c|c|c|c|c|c|c|c|c|c|c|c|c|c|c|c|c|c|c|c|c|c|c|c|c|}
\hline \multicolumn{27}{|c|}{ Yala (Weeks from $4^{\text {th }}$ March to $2^{\text {nd }}$ September) } \\
\hline & 10 & 11 & 12 & 13 & 14 & 15 & 16 & 17 & 18 & 19 & 20 & 21 & 22 & 23 & 24 & 25 & 26 & 27 & 28 & 29 & 30 & 31 & 32 & 33 & 34 & 35 \\
\hline \multicolumn{27}{|c|}{ Mahananeriya } \\
\hline \multicolumn{27}{|l|}{$60-80 \%$} \\
\hline \multicolumn{27}{|l|}{$80-85 \%$} \\
\hline \multirow{2}{*}{\multicolumn{27}{|c|}{$>85 \%$}} \\
\hline & & & & & & & & & & & & & & & & & & & & & & & & & & \\
\hline \multicolumn{27}{|l|}{$60-80 \%$} \\
\hline \multicolumn{27}{|l|}{$80-85 \%$} \\
\hline \multicolumn{27}{|l|}{$>85 \%$} \\
\hline \multicolumn{27}{|c|}{ Alawwa } \\
\hline \multicolumn{27}{|l|}{$60-80 \%$} \\
\hline \multicolumn{27}{|l|}{$80-85 \%$} \\
\hline \multicolumn{27}{|l|}{$>85 \%$} \\
\hline \multicolumn{27}{|c|}{ Maha (Weeks from $2^{\text {nd }}$ September to $4^{\text {th }}$ March) } \\
\hline & 36 & 37 & 38 & 39 & 40 & 41 & 42 & 43 & 44 & 45 & 46 & 47 & 48 & 49 & 50 & 51 & 52 & 01 & 02 & 03 & 04 & 05 & 06 & 07 & 08 & 09 \\
\hline \multicolumn{27}{|c|}{ Mahananeriya } \\
\hline \multicolumn{27}{|l|}{$60-80 \%$} \\
\hline \multicolumn{27}{|l|}{$80-85 \%$} \\
\hline \multirow{2}{*}{\multicolumn{27}{|c|}{ Ibbagamuwa }} \\
\hline & & & & & & & & & & & & & & & & & & & & & & & & & & \\
\hline \multicolumn{27}{|l|}{$60-80 \%$} \\
\hline \multicolumn{27}{|l|}{$80-85 \%$} \\
\hline \multicolumn{27}{|l|}{$>85 \%$} \\
\hline \multicolumn{27}{|c|}{ Alawwa } \\
\hline \multicolumn{27}{|l|}{$60-80 \%$} \\
\hline $80-85 \%$ & & & & & & & & & & & & & & & & & & & & & & & & & & \\
\hline$>85 \%$ & & & & & & & & & & & & & & & & & & & & & & & & & & \\
\hline
\end{tabular}




\section{Suitability of temperature and relative humidity}

Combined effect of relative humidity and temperature which is the most probable condition causing grain sterility (Abeysiriwardena et al., 2002) was considered for the suitability classification in the reproductive phase of rice. This phase should be coincide with the highly suitable category (temporally and spatially) to get the maximum production of rice in the particular area.

Fig. 3 shows the suitability of the combined effect of temperature and relative humidity on a weekly basis during Yala season at Mahananeriya ASC. From $10^{\text {th }}$ June to $1^{\text {st }}$ September, Mahananeriya ASC region shows highly suitable, suitable and moderately suitable categories for rice production, while showing the rest of time period as moderately suitable for the entire area. Spatial variations are evident during the weeks starting from $10^{\text {th }}$ June, $24^{\text {th }}$ June, $1^{\text {st }}$ July, $8^{\text {th }}$ July and $29^{\text {th }}$ July. Entire Mahanaeriya ASC area is highly suitable for the week staring from $17^{\text {th }}$ June and from $15^{\text {th }}$ July to $28^{\text {th }}$ July. If the flowering and anthesis could coincide with this period, maximum production of rice could be achieved. From $5^{\text {th }}$ August to $01^{\text {st }}$ September, entire area could be categorized as suitable for the coinciding reproductive stage. Therefore, crop establishment should be done based on suitability during the reproductive phase. According to the suitability period, crop should be established from $15^{\text {th }}$ April to $27^{\text {th }}$ May considering the age group as $21 / 2$ month, 3 month, $31 / 2$ month, 4 month during Yala season.

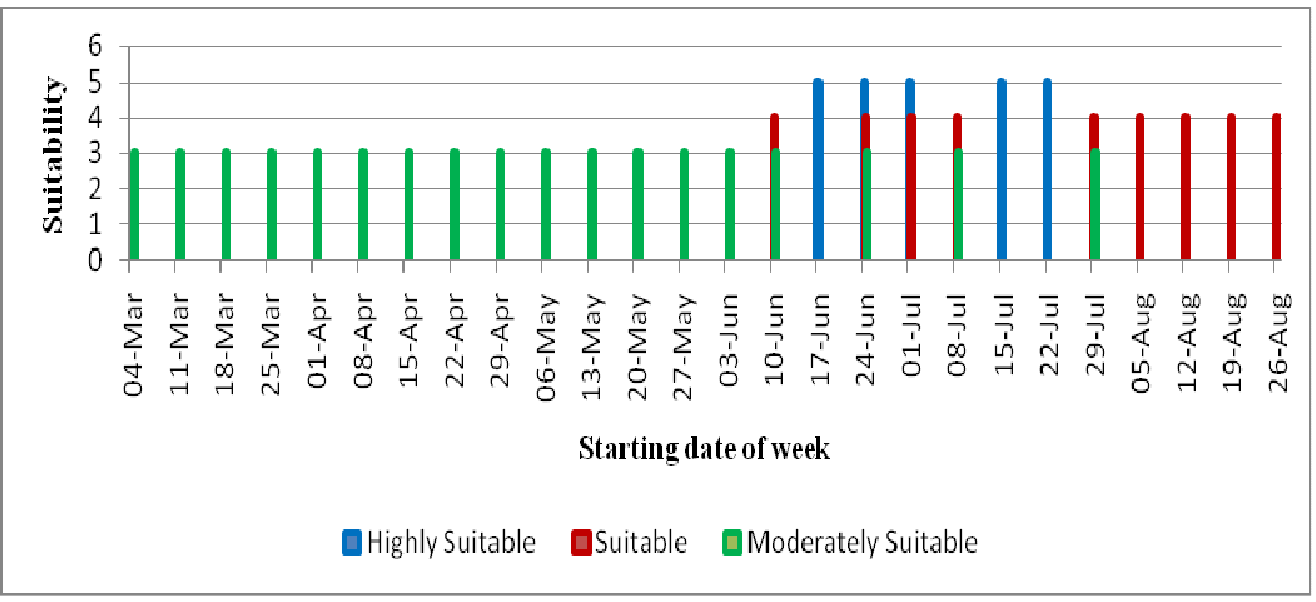

Fig. 3. Suitability of the combined effect of temperature and relative humidity on weekly basis during Yala season at Mahananeriya ASC (Suitability scale: $1=$ not suitable, $2=$ marginally suitable, $3=$ =moderately suitable, $4=$ suitable, $5=$ highly suitable)

During Maha season, entire Mahananeriya ASC region does not show 'highly suitable' period for rice (Fig. 4). Most of the time period is suitable for the whole area except from $7^{\text {th }}$ October to $20^{\text {th }}$ October and from $12^{\text {th }}$ February to $3^{\text {rd }}$ March which shows the 'moderately suitable' period for the entire region. Crop should be established from $7^{\text {th }}$ October to $18^{\text {th }}$ November considering the age group as $21 / 2$ month, 3 month, $31 / 2$ month, 4 month. Establishment of $4 \frac{1}{2}$ months age rice varieties should be done in mid September. If the crop establishment is delayed, flowering stage coincides with the 'moderately suitable' period (from $11^{\text {th }}$ February onwards) and yield reduction can be expected. 


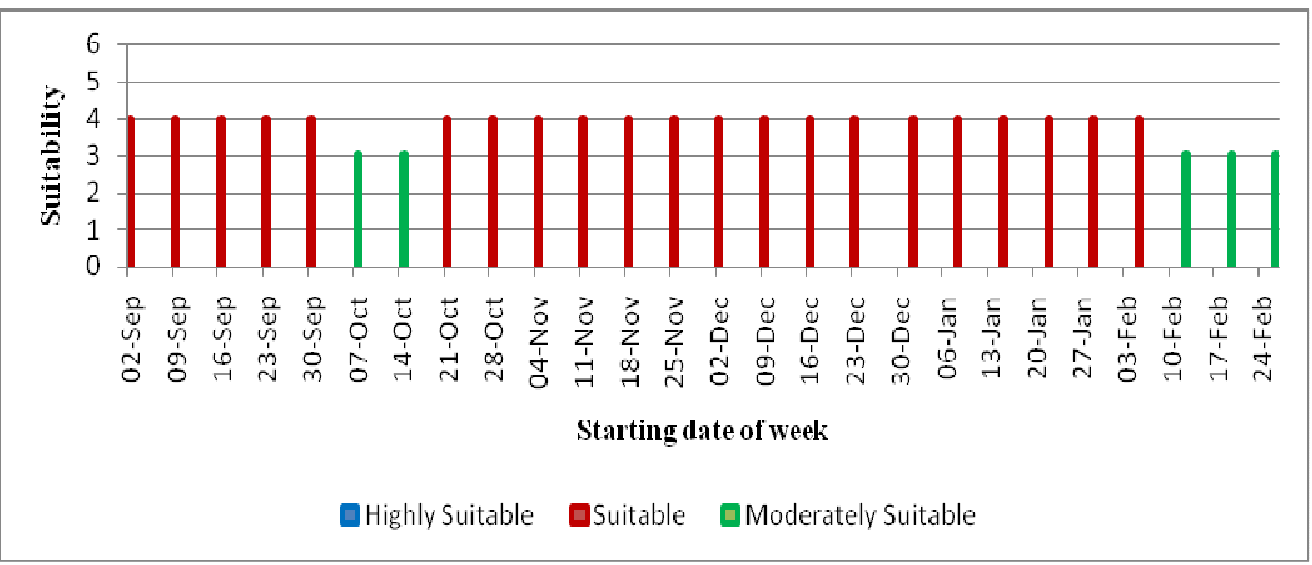

Fig. 4. Suitability of the combined effect of temperature and relative humidity on weekly basis during Maha season at Mahananeriya ASC (Suitability scale: $1=$ not suitable, $2=$ marginally suitable, $3=$ moderately suitable, $4=$ suitable, $5=$ highly suitable)

Entire region of Ibbagamuwa ASC shows the highly suitable period for rice production as from $10^{\text {th }}$ June to $4^{\text {th }}$ August (Fig. 5). Beyond $5^{\text {th }}$ August, spatial variations could be observed within the region. Suitable period for crop establishment is from $15^{\text {th }}$ April to $27^{\text {th }}$ May considering the age group as $2 \frac{1}{2}$ month, 3 month, $31 / 2$ month, 4 month, $4 \frac{1}{2}$ month during Yala season. One week from $15^{\text {th }}$ January shows the 'highly suitable' time for the entire Ibbagamuwa ASC region (Fig. 6) in Maha season. If not, crop should be harvested before $11^{\text {th }}$ February to get a good yield from the entire area which shows the spatial variability as highly suitable and suitable in terms of temperature and relative humidity. Therefore, from $7^{\text {th }}$ October to $18^{\text {th }}$ November crop should be established considering the age group.

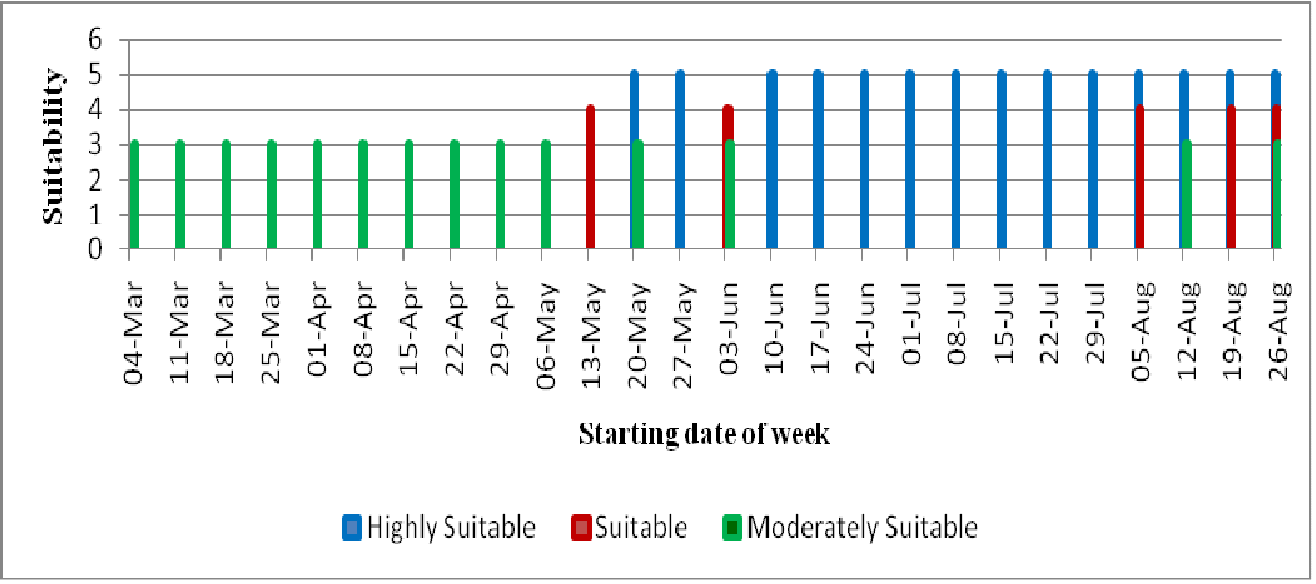

Fig. 5. Suitability of the combined effect of temperature and relative humidity on weekly basis during Yala season at Ibbagamuwa ASC (Suitability scale: 1=not suitable, 2 =marginally suitable, $3=$ moderately suitable, $4=$ suitable, $5=$ highly suitable) 


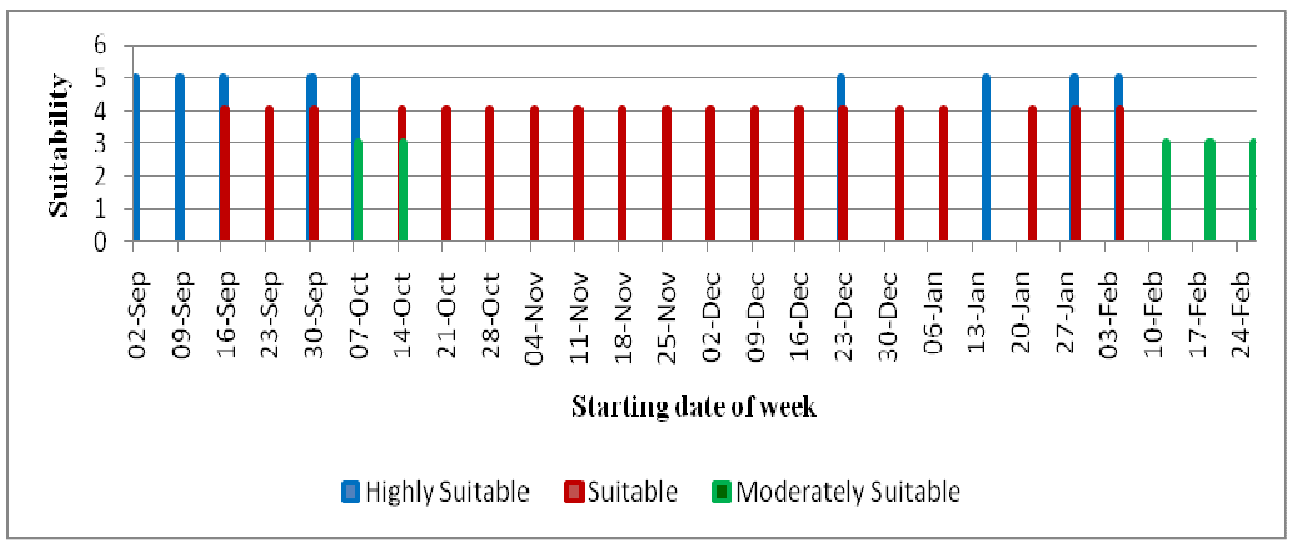

Fig.6. Suitability of the combined effect of temperature and relative humidity on weekly basis during Maha season at Ibbagamuwa ASC (Suitability scale: $1=$ not suitable, 2 =marginally suitable, $3=$ moderately suitable, $4=$ suitable, $5=$ =highly suitable)

Fig. 7 shows that the entire Yala season is highly suitable in entire Alawwa ASC from $27^{\text {th }}$ May onwards. Therefore, the date of crop establishment is not critical during Yala season in this area. During Maha season, Fig. 8 indicates the highly suitable period for flowering and anthesis is from $15^{\text {th }}$ January to $28^{\text {th }}$ January for the entire Alawwa ASC area. However, from $5^{\text {th }}$ February onwards, entire area is moderately suitable for rice production. The most suitable period for Maha season ends on $28^{\text {th }}$ January in Alawwa ASC region. Crop establishment is not a problem since that period is highly suitable or suitable.

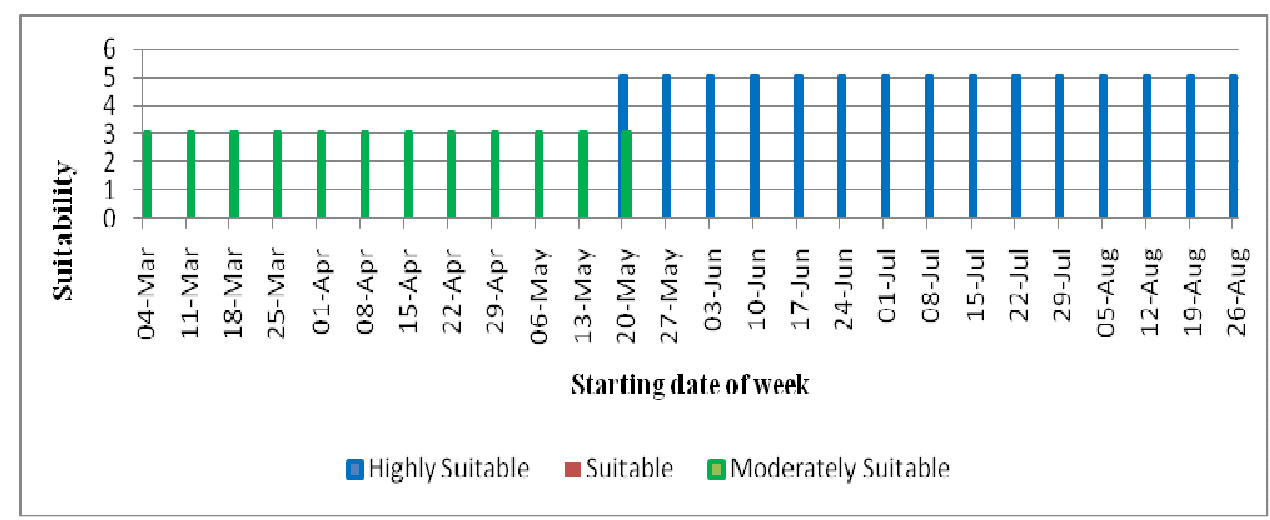

Fig. 7. Suitability of the combined effect of temperature and relative humidity on weekly basis during Yala season at Alawwa ASC (Suitability scale: 1=not suitable, $2=$ marginally suitable, $3=$ moderately suitable, $4=$ suitable, $5=$ highly suitable) 


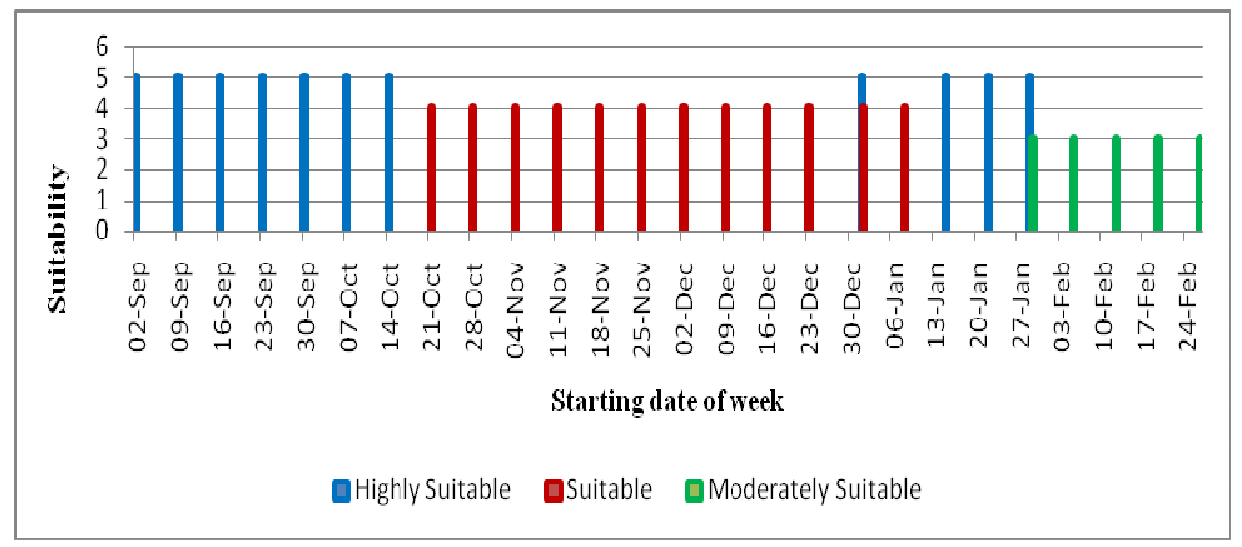

Fig. 8. Suitability of the combined effect of temperature and relative humidity on weekly basis during Maha season at Alawwa ASC (Suitability scale: 1=not suitable, 2 =marginally suitable, $3=$ moderately suitable, $4=$ suitable, $5=$ =highly suitable)

Suitability in terms of the joint effect of temperature and relative humidity of lowland rainfed paddy fields in Mahananeriya, Ibbagamuwa and Alawwa representing Dry (DL1b), Intermediate (IL1a) and Wet (WL3) zones in Kurunegala District during Yala and Maha seasons are shown in Fig. 9, 10, and 11. Spatial variations of the suitability of the interactive outcome of the maximum temperature and relative humidity appear among Mahananeriya, Ibbagamuwa and Alawwa ASC regions representing Dry (DL1b), Intermediate (IL1a) and Wet (WL3) zones in Kurunegala District. Intra regional variations are very rare. Temporal variations among two seasons of Yala and Maha and the variations within the seasons were also evident. 


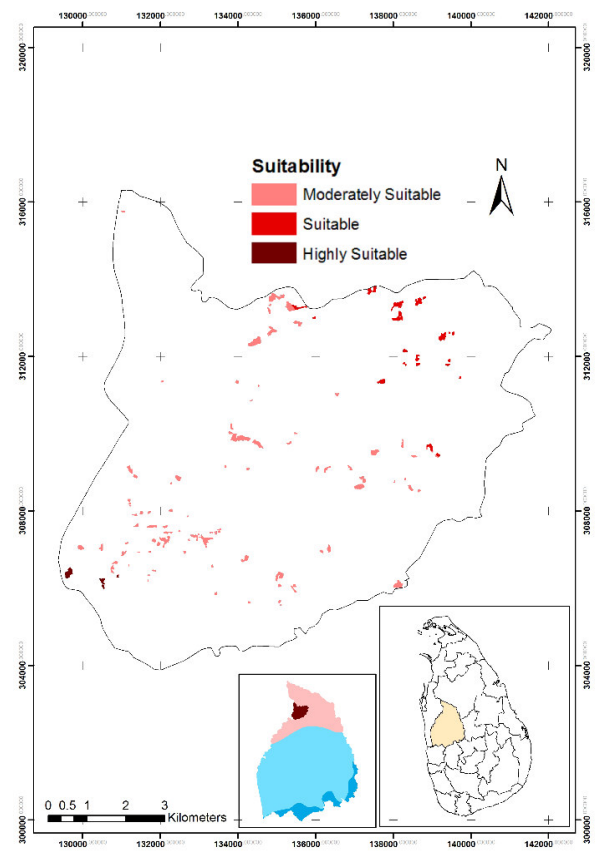

Fig. 9. Suitability of the combined effect of temperature and relative humidity in $26^{\text {th }}$ week (24 June - 30 June) during Yala season at Mahananeriya ASC

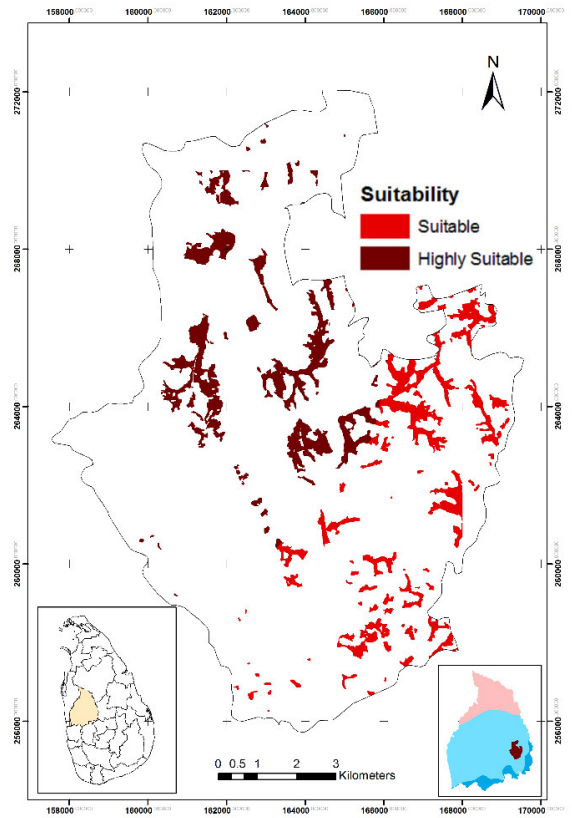

Fig. 10. Suitability of the combined effect of temperature and relative humidity in $6^{\text {th }}$ week (5 February - 11 February) during Maha season at Ibbagamuwa ASC 


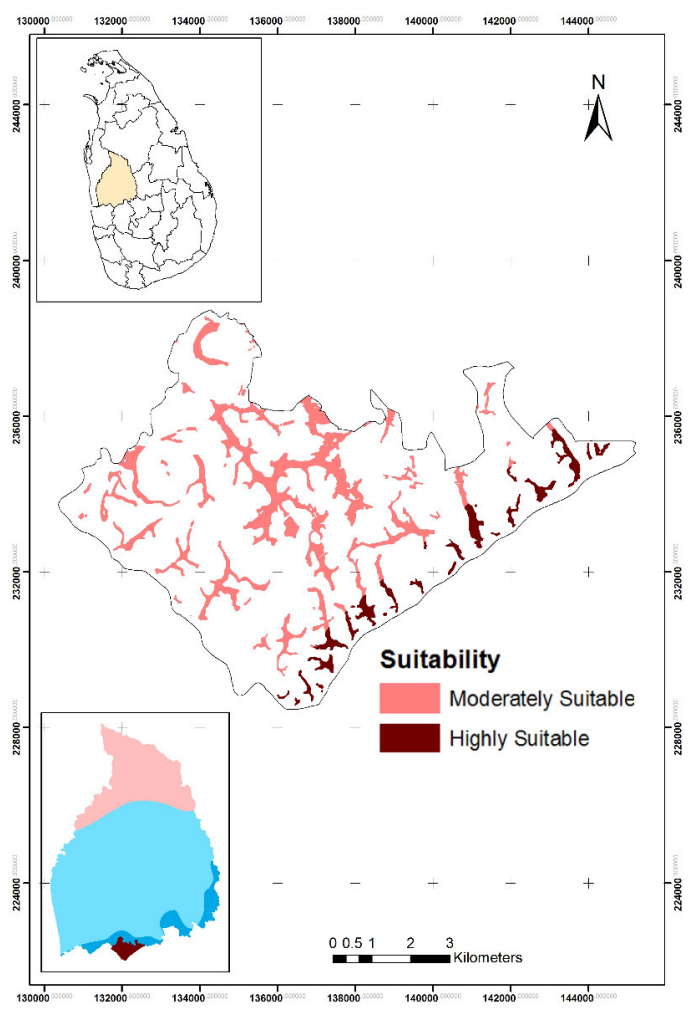

Fig. 11. Suitability of the combined effect of temperature and relative humidity in $21^{\text {th }}$ week (20 May - 26 May) during Maha season at Alawwa ASC

\section{CONCLUSIONS}

Minimum temperature is not in the critical level for rice cultivation within Mahananeriya, Ibbagamuwa and Alawwa ASC areas which represent Dry (DL1b), Intermediate (IL1a) and Wet (WL3) in Kurunegala District. Maximum temperature is at optimum level $\left(27{ }^{\circ} \mathrm{C}-32\right.$ ${ }^{0} \mathrm{C}$ ) for rice cultivation in all three ASC regions during Maha season and in Ibbagamuwa and Alawwa ASCs during Yala season. Temporal variations of maximum temperature were observed within Yala and Maha seasons. Relative humidity in all three ASCs was more than $85 \%$ during Maha season and in between $80 \%$ and $85 \%$ during Yala season. All three ASCs are 'suitable' in terms of the suitability of temperature and relative humidity during Maha season. Entire area of Ibbagamuwa and Alawwa ASCs are 'highly suitable' for rice cultivation during Yala season, while Mahananeriya ASC is suitable. Since temporal variation of temperature and relative humidity was observed in all three ASCs, date of sowing or crop establishment could be aligned to match with the suitability levels during flowering and grain filling of rice. 


\section{REFERENCES}

Abeysiriwardena, D.S.De.Z., Ohba, K. and Maruyama, A. (2002). Influence of temperature and relative humidity on grain sterility in rice. Journal of the National Science Foundation of Sri Lanka. 30, 33 - 41.

De Datta, S.K. (1970). The environment of rice production in tropical Asia. In Rice production manual, International Rice Research Institute, Philippines. pp 53-67.

Farrell, T.C., Fox, K.M., Williams, R.L. and Fukai, S. (2006). Genotypic variation for cold tolerance during reproductive development in rice: screening with cold air and cold water. Field Crops Research. 98, 178 - 194.

Ghadirnezhad, R. and Fallah, A. (2014). Temperature effect on yield and yield components of different rice cultivars in flowering stage. International Journal of Agronomy. [on line]. Available at http://dx.doi.org/10.1155/2014/846707

Jagadish, S.V.K., Craufurd, P.Q. and Wheeler, T.R. (2007). High temperature stress and spikelet fertility in rice (Oryza sativa L.). Journal of Experimental Botany. 58, 1627 - 1635.

Kurtzman, D. and Kadmon, R. (1999). Mapping of temperature variables in Israel: a comparision of different interpolation methods. Climate Research. 13, 33 - 43.

Matsui, T., Namuko, O.S., Ziska, L.H. and Horie, T. (1997). Effect of high temperature and $\mathrm{CO}_{2}$ concentration on spikelet sterility in indica rice. Field Crops Research. 51, $213-219$.

Morita, S. Shiratsuchi, H., Takahashi, J. and Furta, K. (2004). Effect of high temperature on ripening in rice plants: analysis of the effect of high night and high day temperatures applied to the panicle and other parts of the plant. Japanese Journal of Crop Science. 73, 77-83.

In: Shah, F., Huang, J., Cui, K., Nie, L., Shah, T., and Wang, K. (Eds.) Climate change and agriculture paper; Impact of high temperature stress on rice plant and its traits related to tolerance. Journal of Agricultural Science. 2011. Cambridge University Press. pp. 1-12.

Mussie, G.T., Teshome, A.B., Ana C.C. and Marco, P. (2010). Comparison of different interpolation techniques to map temperature in the southern region of Eritrea. $13^{\text {th }}$ AGILE International Conference on Geographic Information Science. pp 1-5.

Nakagawa, H, Horie, T. and Matsui, T. (2003). Effects of climate change on rice production and adaptive technologies. In: Shah, F., Huang, J., Cui, K., Nie, L., Shah,T., and Wang, K. (Eds.) Climate change and agriculture paper. Impact of high temperature stress on rice plant and its traits related to tolerance. (2011). Journal of Agricultural Science. Cambridge University Press. pp 1-12.

Peng, S.B., Huang, J.L., Sheehy, J.E., Laza, R.C., Visperas, R.M., Zhong, X.H., Centeno, G.S., Khush, G.S. and Cassman, K.G. (2004). Rice yields decline with higher night temperature from global warming. Proc. Natl. Academy of Science. 101, 9971 - 9975.

Satake, T. and Yoshida, S. (1978). High temperature induced sterility in indica rices at flowering. Japanese Journal of Crop Science. 47, 6 - 17. 
Weerakoon, W.M.W., Maruyama, A. and Ohba, K. (2008). Impact of humidity on temperature induced grain sterility in rice (Oryza sativa L). Journal of Agronomy and Crop Science. 194, 135 - 140.

Yan, C., Ding, Y., Wang, Q., Liy, Z., Li, G., Muhammad, I. and Wang, S. (2010). The impact of relative humidity, genotypes and fertilizer application rates on panicle, leaf temperature, fertility and seed setting of rice. Journal of Agricultural Science. Cambridge. 148, $329-339$.

Yin, X., Kroff, M.J. and Goudriann, J. (1996). Differential effects of day and night temperature on development to flowering in rice. Annals of Botany. 77, 203 - 213.

Yoshida, S. (1978). Tropical climate and its influence on rice. IRRI Research Paper Series 20. The Philippines: IRRI.

Yoshida, S. (1981). Fundamentals of rice crop science. The Philippines: IRRI.

Zeinab, M., Ahmad, J., Mir, M.K.Z. and Naser, H. (2014). Land suitability analysis for rice cultivation using multi criteria evaluation approach and GIS. European Journal of Experimental Biology. 4(3), $639-648$. 